\title{
Effects of radiotherapy on oral cavity tissues
}

\author{
Marko Dožić, Suzana Stojanović-Rundić, Vesna Plešinac-Karapandžić, Srđan Milanović, Nikola \\ Milošević \\ Institute for Oncology and Radiology of Serbia, Belgrade, Serbia
}

\begin{abstract}
SUMMARY
Radiotherapy in the treatment of head and neck tumors is most often used as an independent method or in combination with surgery and / or chemotherapy. These therapeutic methods in a multidisciplinary approach generally lead to favourable therapeutic response. During radiotherapy of this region, oral mucosa is inevitably covered within irradiated volume. Radical therapy is achieved with high doses of radiation, which usually results in development of undesired toxic effects, which, depending on the time of manifestation can be acute and late. Acute radiation toxicity occurs during or immediately after completion of performed therapy, and the late one several months or years after the completed treatment. The most common acute complications in the oral cavity are inflammation of oral mucosa, loss of taste, dry mouth and secondary infections. Late complications include radiation caries, trismus, and osteoradionecrosis. The aim of this paper was to present the effects and specificities of toxicity observed on oral cavity tissues after radiotherapy.

Keywords: toxicity; radiotherapy; oral cavity; prevention
\end{abstract}

\section{INTRODUCTION}

Ionizing radiation by its effect leads to the formation of free radicals, which interfere with biochemical processes and cell division, resulting in cell death. Radiation is usually carried out in high doses (ranging from 50 Gy to about $70 \mathrm{~Gy}$ ) in individual daily fractions of $2 \mathrm{~Gy}$ during five days a week including breaks over the weekend, and for a total duration of several weeks [1].

Tissues, depending on radiobiological response to radiation, can be radio resistant, and this includes tissues with fewer cell divisions (e.g. bone, cartilage and muscle tissues). In contrast to them, more sensitive to ionizing radiation are tissues whose cells actively divide, such as bone marrow, reproductive organs, eye lens, and digestive and respiratory epithelium. This group also includes mucous membrane of the mouth, therefore it is necessary to prevent these radiation effects and treat them adequately. By applying advanced technologies and using modern radiotherapy techniques, significant precision, better dose distribution and maximum protection of healthy tissues during radiation are achieved thereby reducing possible late toxicity [2].

\section{ACUTE TOXICITY}

Radiation toxicity in the oral cavity occurs in almost all patients who undergo radiation of a tumour in maxillofacial region, all three floors of the throat, base of the tongue, floor of the mouth, parotid region, larynx and neck. The cause of complications is high mitotic activity of mucous membrane cells, disturbance of oral microflora balance with microtrauma produced during normal physiological function of the oral cavity [3]. Acute toxicity most commonly occurs as oral mucositis, loss of taste and dry mouth (xerostomia).

The most common acute complication of radiation is oral mucositis. Cell death of basal keratinocytes under the action of ionizing radiation causes the damage of mucous membrane in the oral cavity. Already during the first week of radiotherapy, early clinical signs of mucositis can be noticed in the form of unclearly localized pale zones or milky white discoloration. They are the most noticeable in the buccal region, especially in the area of mechanical irritation from teeth. These changes are accompanied by mucosal erythema and atrophy. Around this altered epithelium, further action of radiotherapy causes progression of these changes in the form of ulceration. In these spots of mucosal damage, pale yellowish-white fibrin deposits form pseudomembranes and they are suitable place for the formation of infection, usually candidiasis (Candida albicans). In addition to the buccal region, other parts of the oral cavity may also be affected, particularly sides and the upper surface of the tongue, lip mucosa, soft palate, floor of the mouth and throat. Pain is also an important symptom within the onset of first changes and it represents the most significant factor in impairing the quality of life of patients who undergo radiation of head and neck tumours. Due to the presence of pain and disturbed swallowing, patients cannot adequately eat. Particularly the problem is the intake of solid foods and sometimes liquids as well. The pain can vary in intensity depending on the degree of radiation toxicity. As supportive therapy, besides the systemic analgesic therapy based on opioid analgesics, a diet containing dietary supplements rich in proteins is recommended. The most serious form of acute toxicity is complete inability of 
oral food intake. In order to prevent greater than $10 \%$ loss of body mass and anorexia, parenteral nutrition is required and in some cases radiotherapy is discontinued as well [4, 5]. Oral mucositis, depending on the changes observed, is classified by the World Health Organization (WHO) into the four categories (Table 1).

Loss of the sense of taste occurs as a partial reduction (dysgeusia) or a complete loss (ageusia) of all four tastes: salty, sweet, sour and bitter. Partial reduction of the sense of taste often precedes the development of mucositis. This type of toxicity arises in the initial phase of radiotherapy as an acute mucosal reaction due to the damage of receptor cells in so-called gustatory buds on the surface of the tongue. The taste sensory receptor cells are capable of repopulation within four months after the completion of treatment, but also some permanent damage may occur caused by mucositis and dry mouth. The disorder of the sour and bitter sensation is more intense than the disorder of feeling the sweet and salty taste. During radiation it is advised to quit smoking and consuming alcoholic drinks and very spicy foods [6]. The clinical significance of this type of toxicity is the consequent loss of appetite, which significantly affects general condition of the patient. The severity of the loss of taste depends on the dosage of radiation and covered irradiated volume. Usually, the sense of taste returns within the period of up to one year after the completion of radiotherapy.

Dry mouth (xerostomy) occurs as a result of salivary glands damage under the action of ionizing radiation. Oedema of salivary glands happens in the first hours after the beginning of radiation [7], resulting in decreased salivation and increased viscosity of saliva, which becomes thick and sticky. The disorder of salivary gland vascularization is due to fibrotic changes in the blood vessel wall, leading to atrophy and necrosis of glandular cells. This process is irreversible so that dryness of mucous membranes of the irradiated region, although being an acute reaction to radiotherapy, may last for several months or permanently [8]. As the salivary glands are located in different regions of the mouth, xerostomy also depends on the volume of irradiated tissue. Due to decreased salivation, the act of swallowing and eating is disturbed, mostly affecting solid food intake.

\section{LATE TOXICITY}

The effects of late toxicity of radiotherapy can occur few months after the completion of radiation, or years after the treatment. They are chronic, often irreversible and significantly impair the quality of life. Late toxicity is manifested as radiation caries, trismus, and osteoradionecrosis.

Decalcification of the tooth enamel is caused by changes in the chemical composition of the saliva and increased number of cariogenic bacteria in the oral cavity [7], which, in addition to dry mouth and decrease in $\mathrm{pH}$ of the oral cavity, favours caries formation. A special feature of radiation caries is the absence of pain, despite rapid progression and extensive loss of solid substance due to demineralization process of affected teeth [8]. The final result of this process is tooth loss.
Table 1. WHO Oral Mucositis Grading Scale

Tabela 1. Stepen oralnog mukozitisa prema Svetskoj zdravstvenoj organizaciji

\begin{tabular}{|l|l|}
\hline $\begin{array}{l}\text { Grade 0 } \\
\text { Stepen 0 }\end{array}$ & $\begin{array}{l}\text { No presence of oral mucositis } \\
\text { Bez prisustva oralnog mukozitisa }\end{array}$ \\
\hline $\begin{array}{l}\text { Grade I } \\
\text { Stepen I }\end{array}$ & $\begin{array}{l}\text { Erythema, oral soreness } \\
\text { Prisustvo eritema i bolne osetljivosti }\end{array}$ \\
\hline $\begin{array}{l}\text { Grade II } \\
\text { Stepen II }\end{array}$ & $\begin{array}{l}\text { Ulceration; swallowing solid foods possible } \\
\text { Prisustvo ulceracija; očuvana mogućnost gutanja čvrste hrane }\end{array}$ \\
\hline $\begin{array}{l}\text { Grade III } \\
\text { Stepen III }\end{array}$ & $\begin{array}{l}\text { Ulceration; swallowing solid foods impossible; liquid diet only } \\
\text { Prisustvo ulceracija; nemogućnost gutanja čvrste hrane; } \\
\text { tečna ishrana }\end{array}$ \\
\hline $\begin{array}{l}\text { Grade IV } \\
\text { Stepen IV }\end{array}$ & $\begin{array}{l}\text { Ulceration; oral alimentation impossible } \\
\text { Prisustvo ulceracija; potpuna nemogućnost oralnog unosa } \\
\text { hrane }\end{array}$ \\
\hline
\end{tabular}

Trismus represent painful, reduced opening of the mouth caused by spasm of chewing muscles. During radiotherapy using high doses of radiation, development of fibrotic changes in chewing muscles ( $m$. masseter) occurs as well as the reduction of flexibility and extension in the region of temporomandibular joint, with the presence of mandibular hypomobility. These changes usually occur within few months after completion of radiotherapy, and can be that severe that patient can open mouth less than $2 \mathrm{~cm}$, which significantly affects speech and food intake [7]. Sometimes, complete stiffness or ankylosis of temporomandibular joint may occur.

Osteoradionecrosis is one of the most serious late radiation toxicities. It arises as a result of irreversible damage of osteocytes with progressive decrease in microvascularization, which leads to decrease in blood circulation with the consequent hypoxia and tissue hypocellularity. The final result of these changes is osteoradionecrosis with or without secondary infection, with possibility of pathological fracture as well. Mandible is more susceptible to necrosis caused by radiation because of poorer vascularization and bone density compared to maxilla. Symptoms of this process are pain, swelling, fetor, ulceration and orocutaneous fistulas. Osteoradionecrosis usually occurs in the period up to one year after the completion of radiation. Poor oral hygiene and continued alcohol consumption as well as smoking are additional risk factors [9].

\section{PREVENTION}

All patients undergoing radiation therapy must have complete dental examination of the oral cavity before the initiation of the treatment. This involves detailed examination of mucous membranes and teeth, with special focus on decayed teeth that need to be completely repaired. If extraction of the tooth with advanced caries is required, it is necessary to do it 2-3 weeks before starting radiotherapy. Extraction of healthy teeth does not reduce the risk of developing osteoradionecrosis. Radiation mucositis cannot be prevented, but maintaining good oral hygiene can reduce the risk of oral infections. It is recommended to use soft brushes and mild toothpastes during and after radiation [10]. In order to prevent and relieve trismus, it is necessary to introduce regular exercises of chewing muscles all the time during, and for longer time interval after the completion of radiation. 
Of utmost importance for alleviating oral dryness and inflammatory processes is to maintain normal mucous membrane moisture during radiation, so it is advised to do an intensive daily washing of oral cavity with sodium bicarbonate solution and local antiseptics. In case of pain and difficult swallowing, it is necessary to introduce palliative therapy, which often requires introduction of opiates as well.

\section{CONCLUSION}

The prevention of radiation toxicity can be achieved in close cooperation between the radiation oncologist and dentist. It is necessary to visit dentist before the beginning of planned oncologic treatment so that active processes in the oral cavity can be treated, as well as during the implementation of radiotherapy due to the severity of possible complications. With an adequate oral hygiene and increased care of oral mucosa, expected toxicity of radiotherapy can be significantly reduced or prevented.

\section{REFERENCES}

1. Halperin EC, Perez CA, Brady LW. Perez and Brady's principles and practice of radiation oncology. $6^{\text {th }}$ ed. Lippincott Williams \& Wilkins; 2013.
2. Stojanović-Rundić S, Plešinac-Karapandžić $\mathrm{V}$, Ranković $\mathrm{A}$ Obradović K, Dožić M, Tomašević A, et al. Radiation induced toxicity in rectal cancer patients. Review article. Acta Chir lugosl. 2016; 63(1):33-41. [DOl: 10.2298/ACl1601033S]

3. Sciubba J), Goldenberg D. Oral complications of radiotherapy. Lancet Oncol. 2006; 7:175-83. [DOI: 10.1016/S1470-2045(06)70580-0] [PMID: 16455482]

4. Barrett A, Dobbs J, Morris S, Roques T. Practical Radiotherapy Planning. $4^{\text {th }}$ ed. Hodder Arnold; 2009.

5. Pazdur R, Camphausen KA, Wagman LD, Hoskins WJ. Cancer Management: A multidisciplinary approach. $7^{\text {th }}$ ed. Cmp United Business Media; 2008.

6. Dožic M, Stevanović J. Radiotherapy - instruction for patients on radiation therapy. Institute for oncology and radiology of Serbia/ Ministry of health; 2015.

7. Tolentino ES, Centurion BS, Ferreira CL, Souza AP, Damante JH, Rubira-Bullen IR, et al. Oral adverse effects of head and neck radiotherapy: literature review and suggestion of a clinical oral care guidelines for irradiated patients. I Appl Oral Sci. 2011; 19(5):44854. [DOI: 10.1590/S1678-77572011000500003] [PMID: 21986648]

8. Vissink A, Jansma J, Spijkvert FKI, Burlage FR, Coppes RP. Oral sequelae of head and neck radiotherapy. Crit Rev Oral Biol Med. 2003; 14(3):199-212. [PMID: 12799323]

9. Hancock PJ, Epstein JB, Sadler GR. Oral and dental management related to radiation therapy for head and neck cancer. J Can Dent Assoc. 2003; 69(9):585-90. [PMID: 14653934]

10. Gunderson LL, Tepper JE. Clinical radiation oncology. 3th ed. Elsevier. 2012; 30:553-561.

Received: 23.08.2017 • Accepted: 28.11.2017 


\title{
Uticaj radijacione terapije na tkiva usne duplje
}

\author{
Marko Dožić, Suzana Stojanović-Rundić, Vesna Plešinac-Karapandžić, Srđan Milanović, Nikola Milošević \\ Institut za onkologiju i radiologiju Srbije, Beograd, Srbija
}

\begin{abstract}
KRATAK SADRŽAJ
Radioterapija se u lečenju tumora glave i vrata najčešće primenjuje kao samostalna metoda ili u kombinaciji sa hirurgijom i/ili hemioterapijom. Ove terapijske metode u multidisciplinarnom pristupu uglavnom dovode do povoljnog terapijskog odgovora. Prilikom zračne terapije tumora ove regije, oralna sluznica se neizbežno nalazi u obuhvaćenom zračnom volumenu. Radikalnost terapije se postiže visokim dozama zračenja, što obično ima za posledicu pojavu neželjenih toksičnih efekata, koji u zavisnosti od vremena ispoljavanja mogu biti akutni i kasni. Akutna toksičnost zračenja se javlja tokom ili neposredno po završetku sprovedene terapije, a kasna više meseci ili godina od završenog lečenja. Najčešće akutne komplikacije u usnoj duplji su zapaljenje oralne sluznice, gubitak ukusa, suvoća usta i sekundarne infekcije. U kasne komplikacije spadaju radijacioni karijes, trizmus i osteoradionekroza. Cilj ovog rada je bio da se predstave efekti i specifičnosti ispoljene toksičnosti na tkiva usne duplje nakon radijacione terapije, koja značajno utiče na kvalitet života ovih pacijenata.
\end{abstract}

Ključne reči: toksičnost; radioterapija; usna duplja; prevencija

\section{UVOD}

Jonizujuće zračenje svojim dejstvom dovodi do stvaranja slobodnih radikala, koji remete biohemijske procese i ćelijsku deobu, što za posledicu ima smrt ćelije. Zračenje se obično sprovodi visokim dozama (u rasponu od 50 Gy do oko $70 \mathrm{~Gy}$ ) u pojedinačnim dnevnim frakcijama od 2 Gy tokom pet dana u nedelji i sa pauzama tokom vikenda, a u ukupnom trajanju od nekoliko nedelja [1].

Tkiva, u zavisnosti od radiobiološkog odgovora na zračenje, mogu biti radiorezistentna, i tu se svrstavaju tkiva sa manjim brojem ćelijskih deoba (npr. koštano, hrskavičavo i mišićno). Nasuprot njima, na jonizujuće zračenje su osetljivija tkiva čije se ćelije aktivno dele, kao što su koštana srž, reproduktivni organi, očno sočivo, odnosno digestivni i respiratorni epitel. Ovoj grupi pripada i sluznica usne duplje pa je zato neophodno preduprediti ove efekte zračenja i adekvatno je tretirati. Primenom naprednih tehnologija i korišćenjem savremenih tehnika radioterapije postiže se značajna preciznost, bolja distribucija doze i maksimalna zaštita zdravih tkiva tokom zračenja, čime se smanjuje i moguća kasna toksičnost [2].

\section{AKUTNA TOKSIČNOST}

Radijaciona toksičnost u usnoj duplji nastaje kod skoro svih pacijenata kod kojih se sprovodi zračenje tumora maksilofacijalne regije, sva tri sprata ždrela, baze jezika, poda usta, parotidne regije, larinksa i vrata. Uzrok komplikacija predstavlja visoka mitotska aktivnost ćelija sluznice, narušavanje ravnoteže oralne mikroflore uz mikrotraume nastale tokom normalne fiziološke funkcije usne duplje [3].

Akutna toksičnost se najčešće javlja kao oralni mukozitis, gubitak osećaja ukusa i suvoća usta (kserostomija).

Najčešća akutna komplikacija zračenja je oralni mukozitis. Ćelijska smrt bazalnih keratinocita pod dejstvom jonizujućeg zračenja dovodi do oštećenja sluznice usne šupljine. Već tokom prve nedelje radioterapije mogu se primetiti rani klinički znaci mukozitisa, u vidu pojave nejasno ograničenih bledih zona ili mlečno bele prebojenosti. Najuočljivije su u bukalnoj regiji, posebno u predelu mehaničkih nadražaja zuba. Ove promene su praćene eritemom i atrofijom sluzokože. Oko ovako izmenjenog epitela daljim dejstvom zračne terapije nastaje progresija ovih promena u vidu pojave ulceracija. Na ovim mestima oštećenja sluznice nakupljaju se bledo žućkasto-beličaste fibrinske naslage koje formiraju pseudomembrane i koje su pogodno mesto za nastanak infekcije, obično pojavu kandidijaze (Candida albicans). Osim bukalne regije mogu biti zahvaćeni i drugi delovi usne duplje, naročito bočne strane i gornja površina jezika, mukoza predela usana, mekog nepca, poda usta i ždrela.

Bol je takođe važan simptom pri pojavi prvih promena $\mathrm{i}$ predstavlja najznačajniji činilac u narušavanju kvaliteta života bolesnika kod kojih se sprovodi zračenje tumora glave i vrata. Zbog prisutnog bola i poremećenog akta gutanja pacijenti ne mogu da se adekvatno hrane. Posebno im predstavlja problem unošenje čvrste hrane, ali i tečnosti. Bol može biti različitog intenziteta u zavisnosti od stepena ispoljene radijacione toksičnosti. U suportivnoj terapiji se osim sistemske analgetske terapije zasnovane na opioidnim analgeticima preporučuje i ishrana dijetetskim suplementima bogatim proteinima. Najteži oblik akutne toksičnosti predstavlja potpuna nemogućnost oralne ishrane, zbog čega u cilju sprečavanja gubitka telesne mase većeg od 10\% i anoreksije otpočinje parenteralna ishrana, a u nekim slučajevima se i prekida radioterapija $[4,5]$. Oralni mukozitis se u zavisnosti od ispoljenih promena klasifikuje po Svetskoj zdravstvenoj organizaciji (WHO) u četiri kategorije (Tabela 1).

Gubitak osećaja ukusa se javlja kao delimično smanjenje (dysgeusia) ili potpuni gubitak (ageusia) sva četiri ukusa: slanog, slatkog, kiselog i gorkog. Delimično smanjenje osećaja ukusa često prethodi razvoju mukozitisa. Ovaj tip toksičnosti nastaje u početnoj fazi zračne terapije kao akutna reakcija mukoze, zbog oštećenja receptorskih ćelija u takozvanim gustativnim pupoljcima na površini jezika. Receptorske ćelije čula ukusa su sposobne za repopulacije unutar četiri meseca od završenog lečenja, ali može nastati i izvestan stepen trajnog oštećenja, čemu doprinose mukozitis i suvoća usta. Poremećaj osećaja za kiselo i gorko je intenzivniji u odnosu na poremećaj osećaja slatkog i slanog ukusa. U toku zračenja se savetuje prestanak pušenja i konzumiranja alkoholnih pića i jako začinjenih jela [6]. Klinički značaj ovog tipa toksičnosti je u posledičnom gubitku apetita, što značajno utiče na opšte stanje pacijenta. Izraženost gubitka ukusa zavisi od doze zračenja i obuhvaćenog zračenog volumena. Obično se čulo ukusa vraća u intervalu do godinu dana od završetka radioterapije. 
Suvoća usta (kserostomija) nastaje kao posledica oštećenja pljuvačnih žlezda pod dejstvom jonizujućeg zračenja. Edem pljuvačnih žlezda počinje već u prvim satima nakon početka zračenja [7], zbog čega dolazi do smanjenja lučenja pljuvačke, koja postaje gusta i lepljiva, i povećanja njenog viskoziteta. Poremećaj vaskularizacije pljuvačnih žlezda nastaje usled fibroznih promena u zidu krvnih sudova, što dovodi do atrofije i nekroze žlezdanih ćelija. Taj proces je ireverzibilan, tako da suvoća sluznice zračene regije, iako akutna reakcija na radioterapiju, može trajati ili nekoliko meseci ili trajno [8]. Kako se pljuvačne žlezde nalaze u različitim regijama usta, tako i kserostomija zavisi od volumena zračenog tkiva. Zbog smanjenog lučenja pljuvačke poremećeni su akt gutanja i ishrana pacijenata, a poseban problem predstavlja unos čvrste hrane.

\section{KASNA TOKSIČNOST}

Efekti kasne toksičnosti radioterapije se mogu javiti najranije nekoliko meseci od završetka zračenja, odnosno godinama nakon lečenja. Hroničnog su toka, često ireverzibilni i značajno narušavaju kvalitet života.

Kasna toksičnost se manifestuje kao radijacioni karijes, trizmus i osteoradionekroza.

Dekalcifikacija zubne gleđi je uzrokovana promenama u hemijskom sastavu pljuvačke i povećanim brojem kariogenih bakterija u usnoj duplii [7], što uz suvoću usta i smanjenje vrednosti pH u usnoj duplji pogoduje nastajanju karijesa. Posebna odlika radijacionog karijesa je odsustvo bola, uprkos jako brzom napredovanju i obimnom gubitku čvrste materije usled procesa demineralizacije zahvaćenih zuba [8]. Krajnji rezultat ovog procesa je trajni gubitak zuba.

Trizmus predstavlja bolno, ograničeno otvaranje usta uzrokovano grčenjem mišića za žvakanje. U toku sprovođenja radioterapije primenom visokih doza zračenja dolazi do razvoja fibroznih promena mišića žvakača ( $m$. massetera), kao i smanjenja fleksibilnosti i ekstenzije predela temporomandibularnog zgloba, uz prisutan hipomobilitet mandibule. Ove promene obično nastaju nekoliko meseci nakon završetka radioterapije, a mogu biti toliko izražene da je nemogućnost otvaranja usta svedena na manje od $2 \mathrm{~cm}$, što značajno utiče na govor i unos hrane [7].

Nekada može nastati i potpuna ukočenost odnosno ankiloza temporomandibularnog zgloba.

Osteoradionekroza je jedna od najozbiljnijih kasnih toksičnosti zračne terapije. Nastaje kao posledica ireverzibilnog oštećenja osteocita sa progresivnim smanjenjem mikrovaskularizacije, što dovodi do smanjenja prokrvljenosti sa posledičnom hipoksijom uz hipocelularnost tkiva. Krajnji rezultat ovih promena predstavlja osteoradionekroza sa prisustvom sekundarne infekcije ili bez nje, uz mogućnost nastanka i patološke frakture. Mandibula je podložnija nekrozi usled zračenja zbog slabije vaskularizacije i gustine kosti u odnosu na maksilu. Simptomi ovog procesa su bol, otok, fetor, ulceracije i orokutane fistule. Osteoradionekroza nastaje obično u periodu do godinu dana od kraja zračenja. Loša oralna higijena, kontinuirana upotreba alkohola i pušenje predstavljaju dodatne faktore rizika [9].

\section{PREVENCIJA}

Kod svih pacijenata kod kojih se planira zračenje tumora glave i vrata neophodno je pre započinjanja terapije napraviti kompletan stomatološki pregled usne duplje. Ovo podrazumeva detaljan pregled sluznica i zuba sa posebnim osvrtom na kariozne zube, koje je neophodno u potpunosti sanirati. Ukoliko je neophodna ekstrakcija zuba sa uznapredovalim karijesom, istu je neophodno učiniti dve-tri nedelje pre početka radioterapije. Vađenje zdravih zuba ne smanjuje rizik za nastanak osteoradionekroze. Radijacioni mukozitis se ne može prevenirati, ali održavanjem dobre oralne higijene moguće je smanjiti rizik od nastanka oralnih infekcija. Preporučuje se upotreba mekih četkica i blagih pasti za zube tokom i nakon zračenja [10]. U cilju sprečavanja i ublažavanja trizmusa neophodno je uvesti redovne vežbe mišića žvakača, sve vreme tokom i u dužem periodu posle završenog zračenja.

Od izuzetnog značaja za ublažavanje suvoće usta i upalnih procesa je održavanje normalne vlažnosti sluznice tokom zračenja, pa se savetuje svakodnevno intenzivno ispiranje usne šupljine rastvorom sode bikarbone uz lokalne antiseptike. U slučaju pojave bola i otežanog gutanja neophodno je uvesti i antidoloroznu terapiju, koja često zahteva uvođenje i opijata.

\section{ZAKLJUČAK}

Prevencija radioterapijske toksičnosti usne duplje se mora razmatrati u uskoj saradnji radijacionog onkologa i stomatologa, s obzirom na predviđene visoke doze jonizujućeg zračenja, a radi postizanja očekivanog terapijskog odgovora. Neophodna je koordinacija sa stomatologom pre početka planiranog onkološkog lečenja radi saniranja aktivnih procesa u usnoj duplji, kao i tokom sprovođenja zračne terapije, imajući u vidu ozbiljnost mogućih komplikacija. Adekvatnom oralnom higijenom i pojačanom negom sluznice u značajnoj meri se može ublažiti ili sprečiti očekivana toksičnost radioterapije. 